\title{
CROSS VERSUS CRESCENT IN ALBANIA.
}

TO-DAY when, encouraged by the ostensible 1 causes of and excuses for the Great War, the oppressed of centuries raise their heads, it behoves Catholics to look around and abroad, noting how fare their brethren in various parts of the globe. Troubles in foreign as well as adjacent lands are too often dismissed with the comfortable assurance that "these people are always fighting among themselves." If enquiry reveals that grave wrongs are perpetrated with impunity, but also that interference entails risk of financial loss in great commercial transactions, the subject is laid aside and attention directed elsewhere. Thus only can be explained the indifference of Christian communities who equip missions for the Far East, to the desperate plight of Christians close at hand struggling for the right to live under the powerful pressure of ever-triumphant Mohammed.

Constantinople is popularly supposed to be the last stronghold of the Turk in Europe. In reality he is ensconced nearer home amid the impregnable fastnesses of Albania, whence he harries the Christians within reach, imposing his will on these fated slaves who still resist the shining lure of the Crescent. Among the recalcitrants are the Miridite, Malissori, and other Catholic tribes who mistakenly took it for granted that Turkey shared the defeat of her allies in the late war, and that they need no longer submit to the rule of Mohammed but could govern themselves on Christian lines.

Certain international statesmen, however, have found it expedient to invent an "Albania" whose seat of Government is the chief town of the Moslem tribes, thus placing these in the ascendant, or rather ensuring the continuance of their too sadly proved ascendancy. 


\section{Blackfriars}

If Christians of different persuasions can dwell harmoniously in the same State, and if Christians and Mohammedans can exist together sometimes under Christian administration, there is no possibility of Christians getting fair treatment in a land where Mohammedans have the upper hand. Ancient and recent history go to prove this. In vain we are told that the Moslem Government in Tirana is actuated by the kindliest feelings towards the tribes with which Moslems have been at war for centuries ; the impartial observer refuses to believe it, and the Christians themselves not only refuse to believe it but are arming in self-defence, convinced that warfare will be fiercer than ever. Father Anthony Ashikou, of Scutari, was delegated to plead before the League of Nations assembled at Geneva for the right of the Catholics in the North to preserve their own form of tribal government. But he had little success. The founders of Moslem Albania maintain that the movement of the Catholic tribes is unwarranted secession from what is now a modern, constitutional State! Optimistic theorists favour this view, and profess confidence in the promises of the Moslem authorities to treat the Christians fairly. But no human power can persuade these to strengthen the Moslems at Tirana by paying taxes and accepting the Moslem nominees as their governors. The Catholics of the North would gladly fuse with the Greek-Orthodox of the South, but between the two is wedged a solid block of Mohammedans firmly determined not to let their supremacy disappear. This supremacy is, of course, admitted by the Christians in their immediate vicinity to whom foreign advocates of "united Albania" point in confirmation of their statement that the wolf and the lamb lie down together in this wild region of South-East Europe. Near Tirana, where the strong Moslem contingent is rooted, no opposition is forthcoming, 


\section{Cross versus Crescent in Albania}

and yet the new formation does not coalesce. Without the adhesion of two hundred thousand Catholics, the pick of the race, progress is impossible.

Foremost of all the Christian tribes is the Miridite, whose late chief, Prenk Bib Doda, had been held in captivity for over a quarter of a century by the Sultan of Turkey and returned home a greater anti-Islamite than ever. During his absence the tribe had been governed by its ecclesiastical head, a learned Abbot. No Miridite sits on the State Council at Tirana, which is composed of Mohammedans and cowed or nominal Christians, mere pawns in the hands of the dominant element. One may foist Western principles on the new Mohammedan "State," as was done in that monumental failure, "Constitutional Turkey," but no logical student of history can expect the private ownership of Christians to be recognized as inviolable by Mohammedans. Equality of treatment is irreconcilable with custom derived from the sense of Moslem superiority in all lands where the populations are mixed. The Catholic tribes are persuaded that autonomy is necessary not only to their general development, but to their very survival on the bleak slopes they call their own. It will be said that the quality of Albanian Catholicity is such as to repel sympathy on the part of their more advanced brethren elsewhere. But if it is fierce, it is also genuine. Strangers may not lightly penetrate either the wilds of Dibra or the tortuous paths that wind a charmed way to Oroshi; but with a medal of the Blessed Virgin a traveller is pretty safe in Catholic territory. Again, the Sign of the Cross, whether made in the Orthodox or Catholic manner, served formerly in lieu of safe conduct-so that honest Protestants stood a bad chance--but as a rule life is precarious in those remote regions where primitive children of the Church have managed to live but not to thrive. The ways of the 


\section{Blackfriars}

Catholic Albanian may shock, but in some respects they can edify. They do not treasure human life as we do, but the importance of the human soul is not overlooked. The rules regulating the blood-feud are, after all, no worse than those we had, not so long ago, for the practice of duelling still tolerated in some modern States. Only among the Catholic tribes is there any progress made in stamping out the bloodfeud, and the ceremonies connected therewith are touching in the extreme. Albanian justice demands a life for a life, and if the missionary priest succeeds in obtaining from an intending avenger a break with the tradition of his race and the duty to his clan, it is only after long and painful formula. The culprit, too, is subjected to such humiliating penance that very often he prefers to take his chance of the shot that will settle the account in time-honoured fashion. He is made to kneel in public, the instrument of his misdeeds hung round his neck, and listen to the eulogy of his victim from the lips of the victim's nearest male relative and authorized avenger. Only after repeated exhortations by the reverend pacificator, who relates at length the story of the Crucifixion, drawing parallels, and emphasizing Christ's forgiveness, does the avenger consent, in face of the bereaved onlookers, to reconciliation with the slayer. The oftener he repeats to the priest, "I am not yet ready!" the more he is esteemed and the likelier to be excused by the relatives of the murdered man. When at length the psychic moment has arrived he rushes towards the culprit, removes, and hurls afar, the weapon of destruction, raises his enemy, and embraces him in no half-hearted fashion. In very obdurate cases a child in its cradle is brought and placed between the two as an effective softener of the most implacable. When the blood-feud reaches too great proportions and is exercised with undue vindictiveness, the implicated clans are liable 560 


\section{Cross versus Crescent in Albania}

to excommunication, and here the penalties are of a nature to strike horror in the breast of the most hardened Albanian. Namely, the final, most fearsome objurgation is : "May you die as a craven, your pistols undischarged in their holster!" Seldom is it pronounced, for even the women, so secluded as a rule, rush to entreat the impenitent's submission to Mother Church before he brings eternal disgrace on himself and them.

If the Albanian of any creed is in perpetual warfare with all around him, if he has fought the Serb, the Turk, the Italian, the Greek, looking on all as his natural and inveterate enemies, there is no truer friend or more loyal ally when he has uttered the "Bessa," or pact of amity. The "Bessa " of one man is binding on his whole tribe, and only in recent times, after the introduction of what their foreign protectors call "free-thought" and "enlightenment" among the Moslems, have there been instances of its violation. The Christians claim to have upheld the sacredness of the "Bessa" since time immemorial. European politicians of the up-to-date type would have little understanding of the Albanian's fidelity to a plighted word. Infringement of a solemn engagement renders a man outcast so that he loses all the advantages of fellowship in his clan. His death is not avenged, and his status while living is beneath contempt.

Hospitality is one of the most prized virtues of Albania. It is exemplified in the code which prescribes a life for a life among home-dwellers, but seven lives for the murder of a stranger enjoying the privileges of the "Bessa" from a particular clan. The blood-feud penalties have their disadvantages, but there is no doubt that they produce a fine feeling of solidarity among kinsmen. If you have killed my uncle and I am bound in honour to kill yours, or the nearest approach to him, it follows that relationship between 


\section{Blackfriars}

the most distant cousins is fostered, and there is a lively sense of responsibility and a cultivation of very accurate knowledge on matters pertaining to kinship, family history, and tribal obligations. The amenities of social life founded on supposed strict justice may not be pleasant or friendly, but most peoples have passed through similar phases in their evolution towards some form, at least, of Christian civilization.

In the words of the Serbian diplomat, Dr. M. Gavrilovic, the Albanians are now in the thirteenth century and it is unfair to ask them to behave as if they had enjoyed, like Western Europe, immunity from Turkish influence for ten generations. "The Albanian Mohammedans were staunch supporters of the regime of Abdul Hamid and fierce enemies of their Catholic and Greek-Orthodox brothers. The Miridites, who are the most advanced section, were always in opposition to the Mohammedans, and resisted Mohammedan methods. They are now in revolt against the newly constituted Government of Tirana, because it is de facto a Mohammedan Government, and they cannot be reconciled to a yoke against which they have struggled for centuries. They see no chance for cultural progress in the Catholic sense if they have to submit to Moslem direction."

It has already been remarked that the Catholicism of the Albanians has its peculiarities. Their women, for example, are almost as closely sequestered as the denizens of Turkish harems. They do not assist with their menfolk at Sunday Mass, although it is recognized that they are bound once a year to emerge for the reception of the Sacraments. Now that Turkish predations are hemmed, the missionaries are making more headway against prejudices which survive necessity; but Albanian usage still confines woman to the four walls of her home. Let those who until lately proclaimed that women lost caste if they 562 


\section{Cross versus Crescent in Albania}

approached the polling booths throw stones at the Catholic Albanians for extremism in the same sense.

The soil of Albania is uncultivated, and little is known of its mineral wealth, although explorers have attempted to obtain information on these points as well as on the classification of the tribes. One traveller told me that after traversing a great extent of territory inhabited by Catholics, his guide stopped short at a river and refused to cross it. To his knowledge none of his tribe ever did so, for the Crescent reigned on the other side; but after investigation a man of another tribe was found who had a "Bessa" for the moment with the Moslems, so that under his auspices a hurried passage was effected through the hostile region. If that river is now to be bridged, if the Moslems, incited by distant well-wishers, to action, present themselves as lawful successors to the Turkish regime ousted by the Balkan campaign of 1912, they will be received with deadly volleys from Catholic guns. The Christians of this part of Europe are taught by experience. One of their proverbs runs: "The wolf changes his pelt, but not his nature." They will not place themselves in the power of Mohammedanism, be it frankly Turk, or transmuted Albanian. There is, indeed, a fiercer hatred for the Mohammedan Albanian brother than for the Turk at whose hands the Christians have suffered less directly. To advise the Christians to submit to the Moslem oligarchy, which is called "Official Albania," is futile so long as the Catholic tribes have not a prominent share in the Government. That share will never be ceded by the Mohammedan lords, who have, moreover, the protection of interested factors, leaders in the international capitalistic world. The myth of an "United Albania " can be accepted only by those who find it the most convenient device for exploiting the country-the Tirana Government has given large concessions recently-or by philan563 


\section{Blackfriars}

thropists totally unacquainted with the conditions. We read of a noble patriotic group of " free-thinking " Mohammedan Albanians who are at the head of the freshly created State and anxious for the co-operation of their Christian compatriots. We hear of outside intrigue fomenting the internal discord indigenous to the land. Greece and Yugo-slavia are accused of conspiring with their co-religionists to render the benign rule of the Mohammedans impossible. Italy is said to be honestly endeavouring to further the progress of an autonomous Albania in which Christian and Moslem shall possess equal citizenship. For all reply the Miridites, spokesmen of the Christians, assert their position in a memorandum to the League of Nations: "We, Catholics, have never recognized other authority than that of our Chiefs. We will not submit to a Mohammedan Government whose head is a lieutenant of Kemal Pasha, slayer of Armenians. We demand the recognition of a Christian Republic to include Christians of all confessions. . . . We desire to live in peace with our neighbours. . . A A Miridite pays no taxes to Mohammed."

E. Christitch. 